\title{
The New Monetary Aggregates
}

\author{
R. W. HAFER
}

A last decade have changed the composition of assets used by the public to make payments. Examples include the introduction of negotiable orders of withdrawal (NOW accounts), the implementation of automatic transfer systems (ATS accounts) whereby funds from savings accounts can be automatically transferred to checkable deposits, the growing use of money market mutual funds as substitutes for conventional savings accounts, and the dramatic growth in repurchase agreements (RPs). ${ }^{1}$ Because of these and other developments, it increasingly was argued that the existing monetary aggregates did not measure the true financial position of the public and, therefore, were inadequate tools of monetary policy.

In response to these developments, the Federal Reserve Board recently announced redefinitions of the monetary aggregates. ${ }^{2}$ This article describes the new aggregates, compares them to the old measures, and discusses some technical issues involved in their measurement.

\footnotetext{
1For a discussion of NOW and ATS accounts and their effect on the old monetary aggregates, see Steven M. Roberts, "Developing Money Substitutes: Current Trends and Their Implications for Redefining the Monetary Aggregates," Improving the Monetary Aggregates: Staff Papers, Board of Governors of the Federal Reserve System, Washington, D.C., 1978, pp. 147-70. Hereafter, this publication will be referred to as Staff Papers. See also john A. Tatom and Richard W. Lang, "Automatic Transfers and the Money Supply Process," this Review (February 1979), pp. 2-10. An introduction to repurchase agreements is found in Norman N. Bowsher, "Repurchase Agreements," this Review (September 1979), pp. $17-22$.

$2^{x z}$ Announcement," Board of Governors of the Federal Reserve System, Washington, D.C, February 7, 1980.
}

\section{Definitions}

Tables 1 and 2 compare the old and new monetary aggregates. As shown in table 1, the new basic transactions measure - M1A - is essentially the same as the old M1 measure, except for the deletion of demand deposits due to foreign commercial banks and

\section{Table 1}

\section{Comparison of Old and New Transactions-Type Monetary Aggregates}

\begin{tabular}{|c|c|c|c|}
\hline Component & $\begin{array}{l}\text { old } \\
\text { M1 }\end{array}$ & New & $\begin{array}{l}\text { New } \\
\text { M1B }\end{array}$ \\
\hline Currency in eiroulation & $\mathrm{x}$ & $\mathrm{x}$ & $x$ \\
\hline \multicolumn{4}{|l|}{ At conmerclal banks: } \\
\hline $\begin{array}{l}\text { Demand deposits inclusive } \\
\text { of deposits due to torelgn } \\
\text { commercial banks and } \\
\text { offlclat Institutions }\end{array}$ & $\mathbf{X}$ & & \\
\hline $\begin{array}{l}\text { Demand deposits exclusive of } \\
\text { deposits due to torelgn } \\
\text { commercial banks and official } \\
\text { institutions }\end{array}$ & & $X$ & $x$ \\
\hline Now accounts & & & $x$ \\
\hline ATS accounts & & & $x$ \\
\hline \multicolumn{4}{|l|}{ At thrift Institutions: } \\
\hline Demand deposits & & & $x$ \\
\hline NOW accounts & & & $x$ \\
\hline ATS accounts & & & $x$ \\
\hline Credit union share draft balances & & & $x$ \\
\hline
\end{tabular}


official institutions. This change, based on a recommendation of the Advisory Committee on Monetary Statistics, was made because such balances consist primarily of compensating balances held by foreign commercial banks at U.S. commercial banks for services performed. Since the total of such balances is a small percentage of the old M1, this deletion does not produce large discrepancies between the old M1 and new M1A measures, ${ }^{4}$

Until the early 1970s, a clear distinction between interest-bearing deposits and non-interest-earning deposits held for transactions purposes existed. Since then, however, a series of financial innovations and regulatory changes have blurred this distinction. ${ }^{5}$ The significant changes have taken the form of NOW accounts, which were established in several New England states in the early 1970s, ATS accounts, and the rapid growth of credit union share drafts as an alternative payments mechanism. The new M1B aggregate combines those financial items that have the dual characteristic of being held both for check-writing purposes and as savings accounts. Nearly all of these items are interest-bearing checkable deposits. ${ }^{6}$ The new M1A and M1B aggregates focus on those monetary components that are employed primarily as a means of payment.

As shown in table 2, the old M2 aggregate was defined as the sum of currency, demand deposits, savings deposits, time deposits, and time certificates of deposit (CDs) other than those issued in denominations of $\$ 100,000$ or more by large weekly reporting banks. The new M2 measure is much broader in scope. It is calculated by adding savings deposits and small time deposits (those issued in denominations of less than $\$ 100,000$ ) at all depositary institutions, overnight RPs issued by commercial banks, overnight Eurodollars (issued by Caribbean branches of mem-

SSee Improving the Monetary Aggregates: Report of the Advisory Committee on Monetary Statistics, Board of Govemors of the Federal Reserve System, Washington, D.C., 1976, pp. 15-20. Hereafter, this publication will be referred to as Report.

4For example, during 1978 the amount of demand deposits due to foreign-related banking offices averaged less than 2 percent of total demand deposits.

sFor an excellent description of this, see Roberts, "Developing Money Substitutes."

${ }^{6}$ This distinction is necessary because not all of the new checkable deposits are interest-bearing at present. For example, some depositary institutions currently offer non-interest-bearing NOW accounts (NNOWs), and demand deposits at mu" tual savings banks do not currently pay interest. Also, some non-interest-earning demand deposits that are held at thrift institutions and cannot be separated from interestubearing checkable deposits are included in MIB. At present, the amount of such deposits is small. ber banks) held by U.S. nonbank residents, money market mutual fund shares, and a consolidation component to the new MIB measure. This definition includes such a broad array of monetary components and institutions (e.g., commercial banks, U.S. agencies and branches of foreign banks, Edge Act corporations, foreign investment companies, mutual savings banks, savings and loan associations, and credit unions), that it is more directly comparable to old $\mathrm{M} 3$ than to the previous M2 definition (see table 2).

There is, however, one major difference between the new M2 measure and the old M3 definition: The new M2 includes overnight RPs and Eurodollars, and money market mutual funds shares which were not included in the old M3 measure.

The introduction of these items stems from their increasing substitutability for other non-transactions type financial holdings already included in the broader monetary measures. For instance, money market mutual funds shares are viewed as substitutes for other non-transactions-type financial assets, despite the fact that owners of these shares are offered check-writing privileges. The fairly large minimum denomination requirement (usually $\$ 500$ or more) for checks written on these accounts and the fact that these balances typically exhibit relatively slow tumover rates suggest that these accounts are used primarily as savings rather than transactions accounts. ${ }^{7}$

The transactions and investment characteristics of overnight RPs have been subjected to considerable investigation in recent years. For example, studies by Garcia and Pak, Wenninger and Sivesind, and Tinsley, Garrett, and Friar have viewed these RPs as close substitutes for existing demand deposits. Consequently, they have explained a large part of the decline in the public's demand for transactions balances which occurred in the mid-1970s by including RPs in the definition of a transactions-type money (i.e., old M1). In contrast, others have regarded RPs as short-term, highly liquid investment items that are significantly different from demand deposits. ${ }^{8}$

\footnotetext{
"Thomas D. Simpson, "The Redefined Monetary Aggregates," Federal Reserve Bulletin (February 1980), p. 100.

"See Gillian Garcia and Simon Pak, "Some Clues in the Case of the Missing Money," American Economic Review; Papers and Proceedings (May 1979), pp. 330-34; John Wenninger and Charles Sivesind, "Defining Money for a Changing $\mathrm{Fi}$ nancial System," Federal Reserve Bank of New York Quarterly Review (Spring 1979) pp. I-8; Peter A. Tinsley, Bonnie Garrett, and Monica Friar, "The Measurement of Money Demand," Staff Study \#133 (Board of Governors of the Federal Reserve Systen, 1978); and Thomas D. Simpson, "The Market for Federal Funds and Repurchase Agreements," Staff Study \#166 (Board of Governors of the Federal Reserve System, 1979).
} 


\section{Table 2}

Comparison of Old and New Non-Transactions-Type Monetary Aggregates

Component
Gurrency

At conmercial banks:

Demand deposits inclusive of deposits due to torelgn commerclal banks and offcial institutions

$x$

Demand deposits exclesive of deposits due to forelgn commerclal banks and official institutions

Now accounts

ATS accounts

overnight FPS

Savings deposits

Large time deposits

Other than large negotiable $\mathrm{CDs}$

Including large negoliable CDs

Term APs

At thift institutions:

Demand deposits

NOW accounts?

ATS accounts!

Credit union share draft balances

Savings Ceposits Mutual savings banks and savings and loan associations)

Small tine deposits $(<100,000)$

Large time deposits $>\$ 100,000)$

Term HPs (commerclal banks and savings and loan associations)

Other:

Overnight Eurodollar deposits of US nonbank residents?

Money market mutual funds shares

Term Eurodollars held by U.S, nonbank residents

Bankers acceptances

Commercial paper

U.S. savings bonds

Liquid Treasury securities

M2 consolidation component?
Small lime deposits $(<\$ 100,000)$

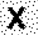

$x$

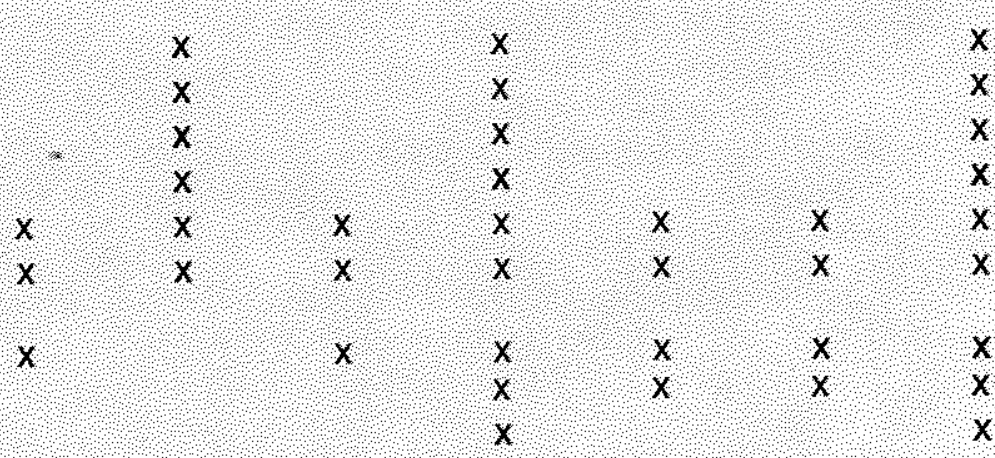

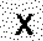

$\mathrm{X}$

$\times$

$\mathrm{x}$

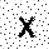

$x$

$\mathrm{X}$

$x$
$x$

$x$

$\mathrm{X}$

$\mathrm{X}$

$\mathrm{x}$

$x$

$\mathrm{X}$

$x$

$\mathrm{x}$

$x$

$x$

$x$

$x$

$x$

$x$

$\mathrm{X}$ -

$\mathrm{X}$ -

$\mathbf{x}$

$x$

$\mathbf{x}$

$\mathrm{x}$

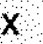

से

$\mathrm{X}$ -

•

s?

s.

$\mathrm{X}$

$+$

$x$

These accounts were included previous y in the savings deposit component of the definitions.

2Ovennght Eurodollars issued by Caribbean branches of member banks.

See text, $\mathrm{P}, 30$, for a discussion of this component. 
There presently is no consensus as to whether overnight RPs and Eurodollars, and money market mutual funds shares primarily constitute transactions- or investment-type assets. These items are included in the new M2 definition. Data on each of these series will be published separately, however, so a direct comm parison of these components with the new transactions aggregates M1A and M1B will be possible.

The new M3 series is defined as new M2 plus large time deposits (those issued in denominations of $\$ 100,000$ or more) at all depositary institutions and term RPs issued by commercial banks and savings and loan associations. The new M3 aggregate is similar to the old M5 definition primarily because of the large-denomination time deposits component. The combination of the large-denomination time deposits and term RPs in this aggregate is based on the belief that these items are relatively close substitutes in many financial portfolios. ${ }^{2}$

The broadest of the new monetary aggregate definitions is the " $\mathrm{L}$ " series. This aggregate, which measures total liquid assets, adds to the new M3 series such financial items as other Eurodollar holdings by nonbank U.S. residents, bankers acceptances, commercial paper, U.S. savings bonds, and liquid Treasury obligations. ${ }^{10}$ This measure closely approximates the credit expansion generated through the commercial banking sector and other financial channels.

\section{COMPARISON OF GOWOWT RATRS}

A comparison of the growth rates of the old and new monetary aggregates provides a useful way to assess the differences resulting from the redefinitions. As shown in table 3 , there is relatively little quantitative difference between the annual growth rates of the M1 aggregate and the new M1A and M1B measures over the 1970-1979 period. For example, the average difference in annual growth rates between $\mathrm{M} 1$ and $\mathrm{M} 1 \mathrm{~A}$ over this period is only 0.18 percentage points, the largest divergence occurring in 1973 when M1 grew 0.5 percent faster than M1A.

"Simpson, "The Redefined Monetary Aggregates," p. 102.

10The Eurodollar holdings included in this measure incorporate those that are not captured in overnight Eurodollars issued by Caribbean branches of member banks. Liquid Treasury obligations consist of those issues with 18 months or less remaining to maturty. See Simpson, "The Redefined Monetary Aggregates," p. 98.

It should also be noted that the new M2, M3, and L aggregates exclude the amounts held by depositary institutions, money market mutual funds, the federal govermment, the Federal Reserve, and foreign commercial banks and official institutions, See Simpson, "The Redefined Monetary Aggregates," pp. 98, 108.

\section{Table 3 \\ Rates of Growth for Transactions-Type Monetary Aggregates}

\begin{tabular}{|c|c|c|c|}
\hline \multicolumn{4}{|c|}{ Annual rate of Growtht } \\
\hline Year & old MI & NeW MIA & New MIB \\
\hline 1970 & $4.8 \%$ & $48 \%$ & $4.8 \%$ \\
\hline 1071 & 6.6 & 6.6 & 6.6 \\
\hline 1072 & 8.4 & 8.5 & 8,5 \\
\hline 1973 & 62 & 6.7 & 58 \\
\hline 1974 & 51 & 47 & 47 \\
\hline 1975 & 46 & 47 & 4.9 \\
\hline 1976 & 58 & 5,5 & 6.0 \\
\hline 1977 & 79 & 77 & 81 \\
\hline 1978 & 72 & 7.4 & 8.2 \\
\hline 1979 & 5.5 & 5,5 & 80. \\
\hline \multicolumn{4}{|c|}{ Quarterly Rate of Growth 2} \\
\hline Quarter & $010 \mathrm{Ml}$ & NeWMIA & New MIB \\
\hline 11975 & $2.0 \%$ & $26 \%$ & $29 \%$ \\
\hline 111975 & 5.8 & 59 & 59 \\
\hline $111 / 975$ & 72 & 70 & 7,3 \\
\hline N/1975 & 3.0 & 29 & 3,2 \\
\hline $1 / 976$ & 4.6 & 54 & 57 \\
\hline $1 / 1976$ & 64 & 5.8 & 6,3 \\
\hline $11 / 1976$ & 41 & 3.4 & 3.9 \\
\hline$V / 1976$ & 74 & 70 & 7,6 \\
\hline $1 / 1977$ & 74 & 88 & 9.3 \\
\hline $11 / 1977$ & 7,4 & 67 & 69 \\
\hline $11 / 11977$ & 8.6 & 60 & 6.5 \\
\hline $1 v / 1977$ & 74 & 8,4 & 8.7 \\
\hline 11978 & 6.6 & 7,6 & 79 \\
\hline $1 / 1978$ & 92 & 87 & 91 \\
\hline $11 / / 1978$ & 79 & 71 & 73 \\
\hline $\mathrm{N} / \mathrm{I} 978$ & 4,3 & 56 & 7.4 \\
\hline $1 / 1979$ & -13 & 0.2 & 4.8 \\
\hline $1 / 1979$ & 81 & 78 & 107 \\
\hline $11 / 11979$ & 97 & 8.8 & 10.1 \\
\hline $1 / / 1979$ & 50 & 47 & 5.3 \\
\hline
\end{tabular}

Fourth quarter-to-fourth-quarter growth rates.

Annualized growth rates based on seasonally adjusted data. SOURCE, The Redefined Monetary Aggregates, table Al.

Although the average difference between the Ml and M1B measures is somewhat larger ( 0.51 percent), $\mathrm{M} 1 \mathrm{~B}$ has demonstrated a faster rate of growth over recent years relative to $\mathrm{M}$. This faster growth -1.0 percent in 1978 and 2.5 percent in 1979 - results from 
Table 4

Rates of Growth for old M2, old M3, and New M2 Monetary Aggregates

\begin{tabular}{|c|c|c|c|}
\hline & \multicolumn{2}{|c|}{ Annual Rate of Growth } & \multirow{2}{*}{ New N12 } \\
\hline Year & old N2 & $01 \mathrm{MB}^{2}$ & \\
\hline 1970 & $7.2 \%$ & $7.2 \%$ & $58 \%$ \\
\hline 1971 & 11.3 & 13.5 & 13.5 \\
\hline 1972 & 11.2 & 13,3 & 12.9 \\
\hline 1973 & 8.8 & 9,0 & 7.3 \\
\hline 1974 & 7.7 & 71 & 60 \\
\hline 1975 & 8.4 & 111. & 12.3 \\
\hline 1976 & 10.9 & 12.7 & 137 \\
\hline 1977 & 9.8 & 117 & 11.5 \\
\hline 1978 & 8.7 & 9.5 & 8.4 \\
\hline 1979 & 8.3 & 8.1 & 8.8 \\
\hline & \multicolumn{2}{|c|}{ Ouarterly Rate of Growth } & \\
\hline Quarter & old Me & Old M3 & Now M2. \\
\hline $1 / 4975$ & $6.4 \%$ & $8.2 \%$ & $7.8 \%$ \\
\hline $11 / 1975$ & 9.5 & 12.4 & 149 \\
\hline $111 / 1975$ & 10.0 & 12.8 & 14.6 \\
\hline v/1975 & 6.8 & 9.4 & 9.9 \\
\hline $1 / 1976$ & 10.5 & 12.0 & 13.0 \\
\hline $11 / 1976$ & 10.0 & 119 & 12.7 \\
\hline 1111976 & 8.9 & 110 & 11.3 \\
\hline $1 / 1976$ & 12.6 & 138 & 15.2 \\
\hline 11977 & 10.9 & 12,4 & 13.7 \\
\hline w/1977 & 9.0 & 10.5 & 11.2 \\
\hline $11 / 1977$ & 10.1 & 11.8 & 9.6 \\
\hline W/1977 & 7.9 & 10.1 & 9.7 \\
\hline $1 / 1978$ & 7.0 & 81 & 7.5 \\
\hline $1 / 1978$ & 8.4 & 8.4 & 7.5 \\
\hline $11 / 1978$ & 9.8 & 10.3 & 8.2 \\
\hline V/1978 & 8.5 & 9.8 & 9.5 \\
\hline //1979 & 28 & 5.3 & 6.3 \\
\hline $1 / 1979$ & 8.8 & 7.9 & 10.2 \\
\hline $111 / 1979$ & 11.9 & 10.5 & 10.3 \\
\hline$V / 1979$ & 89 & 7.8 & 7.2 \\
\hline
\end{tabular}

Stee footnotes accompanying table 3

SOURCF, rle Redefrned Monetary Aggregates, table \&2

the increased use of NOW and ATS accounts as demand deposit and other balances are shifted into these interest-earning checkable deposits.

Growth rates of the old and new M1 measures exhibit greater divergence on a quarter-to quarter basis.
Over the last five years, the average difference between the M1 and M1A quarterly growth rates was 0.80 percent; the average difference between $M 1$ and M1B growth was 1.16 percent. The impact of NOW and ATS accounts again is demonstrated-during 1979, M1B grew 2.5 percent faster than either Ml or MlA. As these figures suggest, the extension of NOW accounts nationwide may temporarily produce wider divergencies between the MIA (and old M1) and MIB growth rates.

Annual and quarterly growth rates for the old M2, old M3, and new M2 measures are presented in table 4. As these figures show, growth rates of new M2 tend to be closer to those of the old M3 definition than to old M2. For instance, the average annual growth rate of old M2 was 9.2 percent over the last decade while the averages for old M3 and new M2 were 10.3 percent and 10.0 percent, respectively. An examination of the quarterly data reveals a similar relationship: From I/1975 to IV/1979, old M2 grew at an 8.9 percent average rate while the average growth rates for old M3 and new M2 were 10.2 and 10.5 percent, respectively. In addition, the proportion of new M2 that consists of money market certificates and money market mutual funds has increased sharply since $1978 .{ }^{11}$

Table 5 presents the annual and quarterly growth rates for the old M4 and M5 aggregates together with the new M3 and L definitions. As noted earlier, the new M3 aggregate is relatively closer in construction to the old M5 measure than to old M4. The difference between the average annual rate of growth of old $\mathrm{M} 4$ and new M3 is 1.2 percentage points; that between old M5 and new M3 is only 0.5 of a percentage point. On a quarter-to-quarter basis, movements in new M3 and old M5 are even more similar. For example, over the period I/1975-IV $/ 1979$, the average quarterly rate of growth of old M4 was 8.1 percent while that of old M5 and new M3 was 9.6 percent and 10.4 percent, respectively.

The growth rates of $\mathrm{L}$ - total liquid assets - have been closer to new M3 than to the other monetary aggregates. While the average quarterly growth rates of $\mathrm{L}$ and new $M 3$ have been roughly similar over the past five years ( 11.1 percent and 10.4 percent, respectively), there has been a growing divergence between these measures in more recent years. This is explained by the rapid growth of liquid assets issued by non-

11Simpson, "The Redefined Monetary Aggregates," p. 105. 
depositary institutions which form the distinction between new $\mathrm{M} 3$ and $\mathrm{L} .{ }^{12}$

\section{MEASURTEG THE NEW AGGREGATES: TECHNICAL CONSTOEIATONS}

Several technical problems arise in the measurement of the new monetary aggregates: Certain deposits held by depositary institutions must be consolidated to avoid double counting, the series used in calculating the new aggregates must be seasonally adjusted, and the data needed to construct the new aggregates must be gathered.

In calculating the old M1 aggregate, the problem of double counting deposits was resolved by netting out cash items in the process of collection, interbank deposits, and Federal Reserve float from total commercial bank demand deposits. ${ }^{13}$ A similar procedure is followed in measuring the new M1A. At the M1B and M2 levels, however, it is assumed that thrift institutions hold demand deposits at commercial banks to service their checkable deposits and ordinary savings deposits. Thus, in calculating M1B, the estimated proportion of demand deposits owned by thrift institutions used to service their checkable deposits will be removed; ${ }^{14}$ for new $\mathrm{M} 2$, total demand deposits owned by thrift institutions are currently netted out.

At the new M2 and M3 levels, further consolidation measures are employed. For instance, in the calculation of new $\mathrm{M} 2$, savings and time deposits owned by all depositary institutions are netted out, and money market mutual funds' holdings of RPs are deducted from the public's holdings of overnight RPs. In addition, CDs held by these funds are also netted out of large time deposits in calculating new M3. Both of these latter items are netted out in the derivation of the total liquid assets aggregate (L).

12For example, the percentage increase in dollar amounts between January 1978 and December 1979 for these items, using seasonally adjusted data, are:

Bankers acceptances ............................. + $+120 \%$

Commercial paper ............................. +48

Short-term Treasury securities ….... +39

U.S, savings bonds .............................. +4

and, based on seasonally unadjusted data, $+136 \%$ for term Eurodollars.

13 For a discussion of this problem, see Report, pp. 12-14; Darwin Beck, "Sources of Data and Methods of Constriction of the Monetary Aggregates," Staff Papers, pp. 117-33; and Simpson, "The Redefined Monetary Aggregates," pp. $107 \times 10$.

14 At the present time, the amount of such holdings is negligible and, therefore, is not omitted from M1B.

\begin{tabular}{|c|c|c|c|c|}
\hline Year: & $\begin{array}{l}\text { Annue } \\
\text { old M4 }\end{array}$ & $\begin{array}{l}\text { late of Gr } \\
\text { Old M5. }\end{array}$ & Nhew M3 & $L$ \\
\hline 1970 & $10.2 \%$ & $9.2 \%$ & $89 \%$ & $6.5 \%$ \\
\hline 1971 & 12.8 & 14.3 & 14.8 & 10.4 \\
\hline 1972 & 12.3 & 13.9 & 14.0 & 12.9 \\
\hline 1973 & 12.0 & 110 & 11.7 & 12.3 \\
\hline 1974 & 10.7 & 0.0 & 8.7 & 9.6 \\
\hline 1975 & 6.6 & 97 & 9.4 & 9.8 \\
\hline 1976 & 7.1 & 10.2 & 11.4 & 110 \\
\hline 1977 & 10.1 & 11.7 & 12.6 & 12,6 \\
\hline 1978 & 10.6 & 10.6 & 11.3 & 12.3 \\
\hline 1979 & 7.5 & 7.6 & 9.5 & $\mathrm{NA}$ \\
\hline & Quarte & Rate of G & with & \\
\hline Quarter & Old M4 & old Ms & New M3 & L. \\
\hline $1 / 1975$ & $7.6 \%$ & $8.9 \%$ & $72 \%$ & $71 \%$ \\
\hline $1 / 1975$ & 5.5 & 9.5 & 9.4 & 9.5 \\
\hline $11 / 1975$ & 6.2 & 10.1 & 107 & 10.5 \\
\hline W/ 1975 & 6.2 & 8.8 & 9.1 & 10.7 \\
\hline $1 / 1976$ & 6.0 & 9.0 & 9.9 & 10.1 \\
\hline $11 / 1976$ & 6.0 & 9.4 & 113 & 11.1 \\
\hline $11 / 1 / 976$ & 6.3 & 9.2 & 10.3 & 10.0 \\
\hline$N / 1976$ & 9.5 & 11.8 & 121 & 10.8 \\
\hline $1 / 1977$ & 10.1 & 11.8 & 124 & 11.5 \\
\hline $1 / 1977$ & 8.3 & 10.0 & 114 & 11.8 \\
\hline $111 / 1977$ & 10.0 & 117 & 117 & 12.2 \\
\hline IV/1977 & 10.4 & 11.5 & 12.5 & 12.8 \\
\hline $1 / 1978$ & 10.2 & 100 & 10.5 & 11.2 \\
\hline $11 / 1978$ & 106 & 9.8 & 111 & 12.4 \\
\hline III $/ 1978$ & 9.9 & 10.4 & 10.3 & 11.3 \\
\hline IV/1978: & 10.1 & 107 & 11.5 & 12.2 \\
\hline $1 / 1979$ & 5.4 & 6.8 & 7.9 & 10.4 \\
\hline $1 / 1 / 1979$ & 3.7 & 4.9 & 8.8 & 13.1 \\
\hline $111 / 1979$ & 9.2 & 8.9 & 10.3 & 11.7 \\
\hline IV/ 1979 & 11.0 & 9.1 & 9.8 & NA. \\
\hline
\end{tabular}

See footnotes accompanying table 3 .

SOURCE: "The Redefined Monetary Aggregates", table A3.

Derivation of seasonally adjusted aggregates follows past procedures wherein the individual compo* nents of the series are seasonally adjusted first, then aggregated to the desired level. ${ }^{15}$ At this time, how-

\footnotetext{
15 See Simpson, "The Redefined Monetary Aggregates," pp, 110-

11. For a general treatment of the seasonal adjustment
} 
Table 6

New and Proposed Data Sources

\begin{tabular}{|c|c|c|}
\hline Institution & Component Collected & Coverage/Frequency: \\
\hline Member banks & 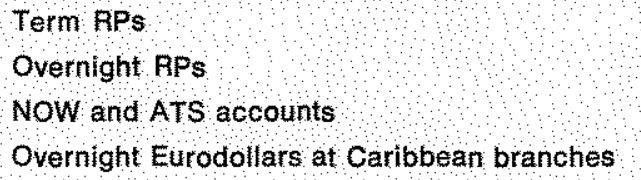 & $\begin{array}{l}125 \text { large member banks/weekly } \\
125 \text { large member banks/weekly } \\
\text { all member banks/woekly } \\
\text { approximately all/weekly }\end{array}$ \\
\hline Nonmember banks & $\begin{array}{l}\text { Demand deposits } \\
\text { Now and ATS accounts }\end{array}$ Savings and small-denominatlon time deposits & $\begin{array}{l}\text { sample/weekly } \\
\text { sample/weekly } \\
\text { sample/weekly } \\
\text { sample/weekly }\end{array}$ \\
\hline Mutual savings banks & $\begin{array}{l}\text { Now accouns and demand deposits } \\
\text { Savings and small denominat on time deposits } \\
\text { Large-denomination time deposits }\end{array}$ & $\begin{array}{l}\text { sample/weekly (Wednesday) } \\
\text { sample/weekly (Wednesday) } \\
\text { sample/weekly (Wednesday) }\end{array}$ \\
\hline Savings and loan assoclations & Now savings and small-denomination time deposits & $\begin{array}{l}\text { sample/thrice-monthly } \\
\text { sample/thrice-monthly } \\
\text { sample/thrice-monthly }\end{array}$ \\
\hline Credit unions & Share dratts Savings and small-denomination time deposits & $\begin{array}{l}\text { sample/ weekly (Wednesday) } \\
\text { sample/weekly (Wednesday) }\end{array}$ \\
\hline
\end{tabular}

The weekly sample (scheduled to begin in March 1980 ) will consist of 70 of the naton's largest credit unions, plus a sample of smaller credit unions to be collected once a month.

SOURCE "The Redefined Monetary Aggregates."

ever, several of the components used to calculate some of the new aggregates are not seasonally adjusted because of data insufficiencies or technical difficulties. The individual series that have not been seasonally adjusted include NOW accounts, ATS accounts, credit union share drafts, demand deposits at thrift institutions, ovemight RPs and Eurodollars, money market mutual fund shares, term RPs at commercial banks and savings and loan associations, and term Eurodollars held by U.S. nonbank residents.

A much wider diversity of financial institutions now participates in the data reporting and collection process (see table 6). Financial institutions that have not been active participants in the previous derivation of the monetary aggregates will play an important role. For example, the Federal Home Loan Bank Board now collects data on NOW accounts held at savings and loan associations; beginning in the spring of 1980 , a sample of large credit unions will provide data on credit union share drafts and related items;

problem, see Report, pp. $37-40$ and, for a techmical discussion, David A. Pierce, Neva Van Peski, and Edward R. Fry,

"Seasonal Adjustment of the Monetary Aggregates;" Staff

Papers, pp, 71-90. the Investment Company Institute provides a weekly survey of money market mutual fund shares; and a daily survey of 125 large member banks forms the basis for the RP series. As this incomplete listing suggests, the comprehensiveness of the new monetary aggregates is greater than the previous measures.

\section{CONCUSONON}

The Federal Reserve Board recently has redefined the monetary aggregates to provide better measures of financial assets held by the public. The new basic transaction measure, called MIA, is equal to the former M1 minus demand deposits held at commercial banks due to foreign commercial banks and official institutions. Large discrepancies between the growth rates of $\mathrm{ML}$ and $\mathrm{M} 1 \mathrm{~A}$ are not anticipated.

In addition, a broader transactions measure M1B - has been introduced. This aggregate com. bines those deposits that are held, for the most part, both for check-writing purposes and as savings accounts. M1B, therefore, equals MIA plus NOW accounts, savings accounts subject to automatic transfer (ATS accounts), credit union share drafts, and 
demand deposits at mutual savings banks (non-interest-bearing). The growth of NOW and ATS accounts has contributed to faster growth of M1B relative to M1 or M1A. Consequently, if NOW accounts are legalized nationwide, more rapid growth in M1B relative to M1A is expected.

The Board also has redefined M2 and M3 and has introduced a new aggregate, $\mathrm{L}$, which is intended to measure total liquid assets held by the public. These redefinitions represent a consolidation of the former M2, M3, M4, and M5 measures, For instance, the new M2 is similar in definition to the old M3; the new M3 is similar to the old M5. The new L aggregate, unlike any previous measure, includes such items as term Eurodollars held by U.S. nonbank residents, bankers acceptances, commercial paper, U.S. savings bonds, and other liquid Treasury obligations. This broad measure of liquid financial assets is believed to provide a useful measure of credit in the economy which arises either through the banking sector or through other financial channels. 